\title{
LEARNING STYLES OF STUDENTS AND THEIR ATTITUDES TOWARD COMPUTER ASSISTED LANGUAGE LEARNING
}

\author{
Nurgül lşık \\ Ms., Boston University, The United States, nisik@bu.edu
}

\begin{abstract}
The main purpose of the study is to determine the correlation between learning styles of students and their attitudes toward computer-assisted language learning (CALL). Given the importance on the role of learning styles and students' attitudes toward computer-assisted language learning, the current study seeks to explore, in more detail, second language learners' perspectives on this issue by asking the following questions:1.What is the correlation between learning styles of students and their attitudes toward CALL? 2.What is the difference between ESL/EFL learners in terms of their attitudes toward second language learning and CALL? The research sample was chosen with the snowball sampling method from the United States and Turkey without looking at their individual differences. All of the 50 participants in the sample were second language learners. For data collection Cohen, Oxford, and Chi's (2002) multi-dimensional Learning Style Survey (LSS) and Min's (1998) Attitude Toward CALL Questionnaire was used in the study. As a result of the study, a positive scale moderately significant relationship was determined between extroverted and inductive learning styles of students, and their attitudes toward second language learning. It is also concluded that the inductive and reflective learning style was moderately correlated with their attitude toward second language learning with computers. In addition, it was found that there was a significant difference between the attitudes of ESL language learners and EFL language learners. In line with this study's findings, further study may be done especially on deductive and inductive learning styles in order to understand how they affect language learning. Other further research focus may be on the differences between ESL and EFL learners' attitudes so as to find out their motivation to learn a language with computers.
\end{abstract}

Keywords: learning styles, attitudes, second language learning, CALL

\section{INTRODUCTION}

Learning style is a significant individual difference in second language (L2) learning. One of the benefits of determining a learning style of a student is that it can be better estimated how he can learn a language and what kind of learning activity should be applied in a language class. Determining the learning styles of individuals and arranging their learning mediums will undoubtedly increase their success (Caliskan and Kilic, 2012, p. 48). According to Cesur and Fer (2009), learning style is the method that the individual has come to get used to for acquiring, processing and storing new information and skills. In other words, learning style represents the approach of the individual to his learning process and his general attitude (p. 290). In that way, learners' attitudes should also be taken into consideration. However, compared to the studies (Sirmaci, 2010; Caliskan and Kilinc, 2012; Brudenell and Carpenter 1990) that give attention to the relationship between students' learning styles and their attitudes toward a specific major, there has been less research on computer assisted language learning in terms of the connection between these two concepts. Regarding the importance of this relationship of learning styles and learners' attitudes, the present study seeks to 
investigate whether there is a correlation between learning styles and attitudes of students in regard to computer assisted language learning.

\section{LITERATURE REVIEW}

Individual differences have been the main topic of second language acquisition because of how they steer the student to learn something new in his education pathway. The most striking one among them in relation to education is learning styles because of the way one's learning style defines the management of the learning process. According to Pritchard (2014), literature provides useful definitions of learning style and is defined variously in a range of different ways. Some of them are;

- "a particular way in which an individual learns,

- a mode of learning-an individual's preferred or best manner in which to think,

- process information and demonstrate learning,

- an individual's preferred means of acquiring knowledge and skills,

- learning style is strategies or regular mental behaviors concerning learning, particularly deliberate educational learning, that a person displays." (p. 46)

Mori (1999) defines learning styles in his article as individual differences in approach to tasks that can make a difference in the way of the learning process and, potentially, in the efficacy with which a person perceives, learns, or thinks. Boneva and Mihavo (2012) stated, "when discussing learning style, we must also consider an individual's preferences when organizing and presenting information" (p. 5). From the conclusion of these definitions, learning styles may have more influence than previously realized. Preferred styles can guide the way people learn a language. It also can change the way one internally represents experiences or recalling information, and can even affect the words chosen while speaking. In that way, the role of learning styles in a language class is an important factor which both students and their teachers should feel most strongly about in order to spend time in their lessons more efficiently. There can be a mismatch between learning styles of students and their teachers' way of teaching as Oxford, Ehrman, Lavine (1991) research study explain that such conflicts can have a great impact on learning. To avoid, or at least resolve, such conflicts, Oxford and her colleagues (1991) suggest that students' and instructors' styles must be surveyed at the beginning of the course and then the information can be used to understand the style dynamics for that particular class. The most striking research that has been done in this area was conducted by Kara (2009). The research focused on learning styles and teaching styles with the help of a case study in the foreign language classroom. This study investigated the hypothesis that there is a mismatch between teaching styles of the teacher and learning styles which results in failure, frustration and demotivation of students. One hundred second-year language learners studying in the English Language Teaching (ELT) Department and 12 teachers who were teaching these groups participated in the study. The results showed that learning styles and teaching styles matched at the ELT Department. Regarding the results of the case study, learners explained how they feel unhappy and frustrated when their teachers do not teach in their favored style. Teachers stated that when they became aware of a mismatch, they would change the activity they gave to the students in the language class (Kara, 2009, p. 81). Therefore, determining the student's learning style is important even for teachers so that their students can become more active in the second language learning process.

Students from all over the world prefer to go abroad to improve themselves in education in order to get different perspectives. Therefore, schools become more diverse in population and the need for attaining knowledge in terms of forming a balanced and equal learning environment becomes a problem which needs to be solved by researchers. The first step that researchers have taken to deal with this problem is that they have defined exactly what learning styles are and which kind of instruments can be helpful to reflect them. Myftiu (2015) stated that, "Educators working with diverse student populations have shown a great deal of interest over the years in the construct of learning styles" (p. 214). With this aim, the first instrument widely known in the second language field was constructed by Reid's (1995) which is the Perceptual Learning Style Preference Questionnaire (PLSPQ) and developed in 1984. Cesur and Fer (2009) explained that in the following years, specifically during the 1990s, there has been a vast amount of research on the role of learning styles in second language learning. Oxford's (1993) Style Analysis Survey (SAS), and Cohen, Oxford, and Chi's (2002) Learning Style Survey (LSS) are some of the most widely-used and well-known instruments in that field. Cohen constructed the Learning Style Survey instrument together with Oxford and e Chi (Cohen, Oxford, and Chi, 2002, p. 15). As for Cohen and Weaever (2005), they divide learning styles into three categories which are sensory/perceptual, psychological/personality, and cognitive. These categories give an overview about the characteristic of students' learning styles $(p, 8)$. All the aspects of learning styles which are covered within these three categories in Learning Style Survey (Cohen, Oxford, Chi, 2002) are explained with the help of eleven activities representing different aspects of learning styles. 
As in the Cohen, Oxford, Chi's LSS (2002), sensory/perceptual learning styles are visual, auditory and tactile/kinaesthetic; psychological/personality learning styles are extroverted, introverted, random-intuitive, concrete-sequential, closure oriented and open oriented; and cognitive learning styles are global, particular, synthesizing, analytic, sharpener, leveler, deductive, inductive, field-independent, field-dependent, impulsive, reflective, metaphoric and literal. According to Cohen, Oxford and Chi (2002), the objectives of the LSS are to raise students' awareness of their learning style preferences, to encourage students to expand their learning style repertoire and to help students get to know each other and foster respect for an awareness of diversity in learning styles.

Lee and Kim's (2014) study is one of the studies in which the Learning Style Survey (2002) was applied to the participants. The researchers investigated Korean students enrolled in the university level of English as a foreign language (EFL) and their learning style preferences and implications for the efficacy of the English learning process. There were 496 subjects included in the research study (Lee and Kim, 2014, p. 118). The findings of the study indicated that Korean learners' auditory style preference was noticeable, and visual and individual learning styles were also considered to be primary learning styles, whereas tactile, kinaesthetic, and group learning styles were less favored (Lee and Kim, 2014, p. 121). Lee and Kim's (2014) study suggested that the learners wanted to learn English with more emphasis on a visual-driven independent style than on an experience-driven collaborative style. Additionally, a majority of the learners maintained or reinforced their preferences throughout the course, and tended to obtain relatively better English achievement results than learners who substantially changed their preferences (Lee and Kim, 2014, p. 129).

According to Lee and Kim (2014), "Many researchers have contributed to learning style research in relationship to SLA for decades. Two types of research have focused on albeit overlapping areas in various studies: style identification and relationship analysis between learner style and other variables" (p. 120). However, few studies have attempted to compare or to find a relationship between learning style and attitude toward computer-assisted language learning (Brudenell and Carpenter, 1990, p. 79). As an example of the second type of research, Caliskan and Kilinc's (2012) study is a prime case because it compared two variables at its core which were learning styles and attitudes of the students toward a specific course. The objective of that study was to explore the relationship between the learning styles of primary school students and their attitudes towards a social studies course (Caliskan and Kilinc, 2012, p. 51). That study also aimed to examine the change between their learning styles and attitudes towards the social studies course according to their classes (Caliskan and Kilinc, 2012, p. 51). Caliskan and Kilinc (2012) explained that, "Reid's (1987) Perceptual Learning Style Preferences Survey and Attitude Scale for Social Studies Course has been used as data acquisition tools. As a result of the study, a positive and medium scale statistically significant relationship has been determined between the learning styles and the attitudes of students" ( $p$, 53). Besides, they concluded that there was a statistically significant difference between the auditory, kinaesthetic and tactile learning styles between classes, and that no difference had been determined between the other styles (Caliskan and Kilinc, 2012, p. 54). Even if social studies is a different topic from second language learning, that study is important for this research because both of their main concerns are very related to each other, which are learning styles and the attitudes of students.

Due to less research on computer-assisted language learning regarding the correlation of learning styles and attitudes of students, that study is a good example to follow as a model. A similar study was conducted by Sirmaci (2010) that dealt with the understanding of the relationship between ninth year students' attitude to mathematics and their learning styles. In that study, it was also investigated whether the students' attitudes and learning styles varied according to their gender and academic achievement in mathematics (Sirmaci, 2010, p. 640). According to Sirmaci (2010), "In the data collection of the research, Mathematics Attitude Scale and Learning Style Inventory were used, and data were collected from 190 students in regular course hours by going to schools" ( $p, 644)$. After the data analysis, it was determined that there was a significant positive relationship between ninth year students' attitudes toward mathematics and their learning styles (Sirmaci, 2010, p. 644). In that study, no difference was found between the learning styles of ninth grade male and female students in the sample because it was seen that both female and male students, to a great extent, had a visual learning style (Sirmaci, 2010, p. 648). With regard to that study, it is deduced that there is no effect of gender variable on learning styles and attitudes. This finding is important because gender was considered as a null hypothesis for this current study.

One of the most related studies is Brudenell and Carpenter's (1990) research on adult learning style and attitude toward computer-assisted instruction (CAI). This study explored the changes in attitudes and the direction of these changes based on experience. The problem studied was to determine the relationship between learning style and attitudes toward CAI. The CAI program, which is a commercially available software program, for nursing research was used in conjunction with a junior level nursing research course throughout the semester (Brudenell and Carpenter, 1990, p. 80). One group pre- and post-test design, two 
questionnaires were administered to 40 adult students. In this research, it was concluded that there were significant changes in attitudes toward CAl for each of the four learning styles (accommodators, convergers, assimilators, and divergers). Assimilators, who rely on abstract conceptualization and reflective observation, were also significantly more negative in overall attitude, as well as the subscales of creativity and function (Brudenell and Carpenter, 1990, p. 81).

As for attitude, Simsek (2000) classified attitude as: "an individual's personal preferences and choices under certain circumstances" (as cited in Hussein et al., 2009, p. 433). Hussein, Demirok and Uzunboylu (2009) drew attention to the topic of attitudes by saying that, "There is an increase in research based on learning a language through negative or positive factors. Especially researches, based on the attitudes in learning a language, aim to successes and the factors which affect these attitudes" ( $p, 432)$. For example, Gomleksiz's (2010) study concluded that sophomores' attitudes were more positive than freshmen in terms of interest, self-confidence, usefulness and teacher subscales. Sophomores' tendency towards learning English was higher than freshmen's (p. 917). In that study, it was also found that in relation to department variables, students' attitudes varied from one department to another, and the results revealed statistically significant differences between the attitudes of the students toward learning English. The students enrolled in the department of Turkish Language Education tended to have more positive attitudes than the other student groups in regard to second language learning (Gomleksiz, 2010, p. 918). The findings from that study may reveal another question which is whether attitudes of learners studying second language (ESL) can differ from those studying a language as a foreign language (EFL). Due to the fact that the main concern of the current study is about language learning, the difference between these two groups is important for the current study.

Of the few studies specifically examining computer-assisted language learners' attitudes, the most influential one is probably Min's (1998) attitudes research. The purpose of the study was to examine the attitudes of a sample of Korean adult English language learners toward computers and their use as a learning tool. One of the research questions of Min's (1998) study was what the attitudes were of Korean adult English language learners toward the learning of English Language as a foreign language. A new instrument was developed especially for this study separately in terms of the students' attitudes toward language learning and computers. The questionnaire consisted of 45 10-point Likert scale items, and three parts: respectively, attitudes toward English learning, attitudes toward computers in general, attitudes toward English language learning with computers. 603 adult Korean students took part in the study. It is interesting that according to Min (1998), the results of the study showed no significant differences between the attitudes, gender and age. However, significant differences were found in the items related to obtaining a job and earning a living. College students were in more agreement about these items compared to the others who were homemakers or those working in industry or business (Min, 1998, p. 71).

Considering all the studies mentioned in this paper, learning styles of students are very important in order for a teacher to make a lesson more understandable according to the needs and styles of individual students. As More (1987) explained, 'in practice, teachers need to be highly sensitive to students' emerging needs and capabilities, to deploy a range of techniques to facilitate and accommodate students of varying abilities and learning styles, and to harness the benefits of each mechanism to ascertain that every student benefits from at least one of them" (p. 26). Swailes and Senior (1999) gave an example in their article that some prefer to learn through reading and reflecting on how this might apply to their own experience, whilst others prefer to learn through trying ideas out and then reviewing their experience before planning the next step. It is important for a teacher to know about learners' styles so as to learn about learners' preference for the materials may be used in the process of language learning. In that sense, Gomleksiz (2010) explained that the role of the teacher is an important factor to develop a positive attitude towards learning language. The teachers should provide a more active, free learning environment for their students. Poor attitudes towards learning a language prevent students from participating in classroom activities or online classes actively.

\section{RESEARCH QUESTIONS}

Given the importance on the role of learning styles and students' attitudes toward computer-assisted language learning, the current study seeks to explore, in more detail, second language learners' perspectives on this issue by asking the following questions.

1. What is the correlation between learning styles of students and their attitudes toward CALL?

2. What is the difference between ESL /EFL learners in terms of their attitudes toward second language learning and CALL?

\section{METHOD}

This study is a correlational research because it focuses on the relationship between two closely connected 
variables.

A total of 50 participants were chosen with the snowball sampling method from the United States and Turkey without looking at their individual differences such as age, gender, personalities, and occupations. These variables were considered as a null hypothesis. For the purposes of this study, the second language referred only to learners of English, whereas foreign language referred to learners of any other language.

For data collection, a questionnaire survey was formed to elicit language learners' responses in terms of learning styles and their attitudes toward computer-assisted language learning. The questionnaire consisted of three parts: a background information section and two Likert-scale response sections. First, brief information about the study was written on the survey to inform the participants about the concept of the research. Also, the consent of the participants about their willingness to take part in the study was asked at the beginning of the survey. The participants had to choose 'YES' if they agreed to join the survey. Then, the participants were asked about their background information such as their names, nationalities, first and second languages, whether they are a student now or not, and how long they have studied their target language. After that, Cohen, Rebecca and Chi's (2002) Learning Style Survey were applied to the participants so as to understand their learning styles in the second section. This survey consisted of 110 Likert-scale items and 11 major activities representing 23 different aspects of learning styles.

In the last section of the research, Min's (1998) instrument was adapted in order to measure the attitudes of the participants toward computer-assisted language learning. According to Min (1998), this questionnaire was produced in 1997 from the answers to the open-ended questions which were given to 60 advanced level students. During the research, 45 items were asked on the sample and the students had to choose the best option for them from a 10-point Likert Scale $(0=$ least positive, $10=$ most positive). This questionnaire was chosen specially to support the validity of the instrument by comparing the previous experiment's results. Min's (1998) instrument consisted of three parts which were respectively about attitudes toward English learning, attitudes toward computers in general and attitudes toward English language learning with computers. In that study, all the results between second language learning and computer-assisted language learning were compared to find out the effect of computers on language learning. With the same aim, all three parts of Min's study was used in this current study. 10 point Likert scale was changed to 5-point Likert scale in order to make neutral point in the middle. Therefore, students could give more definite answer instead of deciding between 5 and 6 points in a 10-point scale. In addition, Min (1998) was searching for only English language learning as s second language L2. For the purpose of this study, second language referred to learners of English, whereas foreign language referred to learners of any other language. Because of that, the term 'English' was omitted and replaced with 'language' in this research. Stockwell (2014) stated that,

"The starting point for research may also be the technology itself. In this way, it becomes evident that the relationship between research and technology is a mutually dependent one, where it would be rather difficult for one element to exist without some effect on the other two" ( $p, 26)$.

As a conclusion of the agreement with Stockwell's (2014) statement, in terms of data collection, all items of the questionnaire were written online thanks to online questionnaire software, and the link to the survey was distributed via e-mail. Each survey lasted approximately 20 minutes, and the participants were given the option of continuing the study.

Some students did not continue or passed some sections of the survey without answering. These students' answers were not accepted as valid data to examine for the statistical analysis. The link of the survey was sent to 50 students electronically, but 20 of them were excluded from the data for the sake of accurate data analysis. Then, the data obtained from students were transferred to the SPSS package software. In line with the objective of the study, required statistical calculations were made using correlation, t-test analysis. In addition, some figures and descriptive data were used to give additional information about the sample.

\section{RESULTS}

This section includes findings obtained as a result of statistical analyses on the acquired data. All research questions were revaluated in this section according to these findings.

\subsection{Research Question 1}

First of all, a bar chart was used to get a general idea about the sample's learning styles. Figure 1 reflects the student's learning styles preferences according to data obtained from Cohen, Rebecca and Chi's (2002) questionnaire. Figure 1 shows that the three most preferred learning styles are Field-Independent, Synthesizing and Visual learning styles, whereas the least preferred ones are Auditory, Field-Dependent and 
Tactile learning styles.

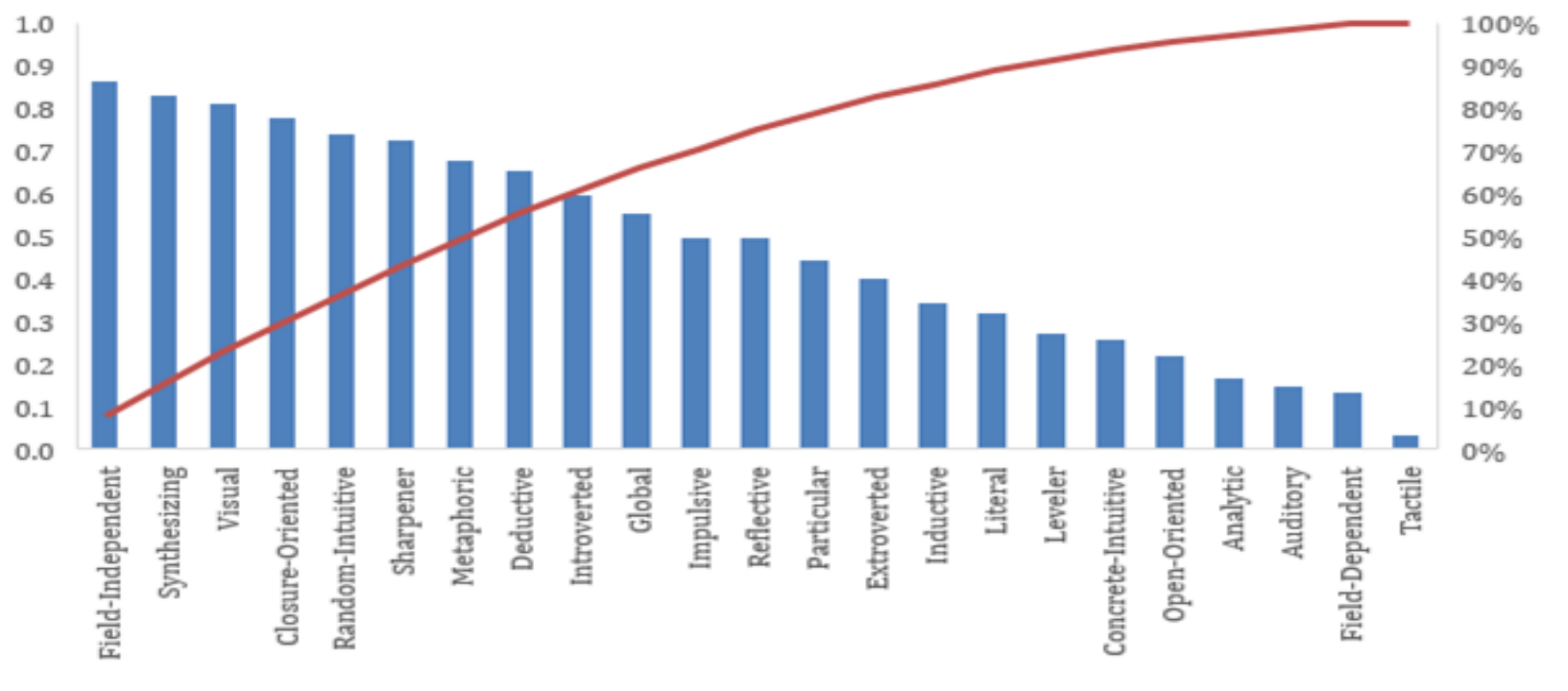

Fig. 1. Learning Styles Distribution in Total

Then, in terms of the first research question regarding the correlation between learning styles and the attitudes of the students toward CALL, Pearson Correlation Coefficient data analysis was conducted to all variables, including attitudes (three concepts of attitudes), and all the learning styles which consist of twentythree types. In total, there were twenty-six variables in this study based upon the research question. In Table 1 , the first column shows the correlation of attitudes toward second language learning (first part of Min's questionnaire) and the other variables, which are all learning styles. The value of $r$ which measures the strength and direction of a linear relationship between these variables (positive or negative) is calculated as Table 1

Pearson's Correlation Coefficient between learning styles and second language learning

\begin{tabular}{|c|c|c|c|c|c|c|c|c|c|c|c|c|c|c|c|c|c|c|c|c|c|c|c|c|}
\hline & 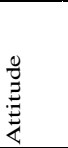 & 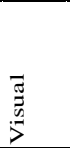 & 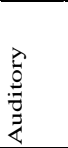 & 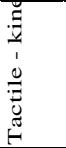 & 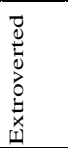 & $\begin{array}{l}0 \\
0 \\
0 \\
0 \\
0 \\
\Xi \\
\Xi\end{array}$ & 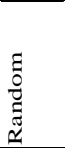 & $\begin{array}{l}0 \\
0 \\
0 \\
0 \\
0 \\
0\end{array}$ & $\begin{array}{l}\stackrel{0}{3} \\
\stackrel{0}{0} \\
\stackrel{0}{U}\end{array}$ & $\begin{array}{l}\text { D̃ } \\
\text { oี }\end{array}$ & $\begin{array}{l}\bar{\pi} \\
0 \\
0 \\
0\end{array}$ & 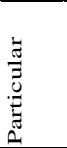 & 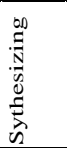 & 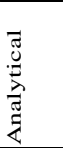 & 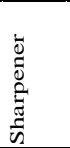 & $\begin{array}{l}\overline{0} \\
\frac{0}{0} \\
j \\
j\end{array}$ & 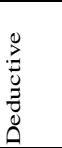 & $\begin{array}{l}0 \\
\stackrel{\Xi}{0} \\
\Xi \\
\Xi \\
\Xi\end{array}$ & 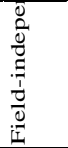 & 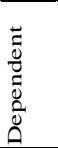 & $\frac{\sum_{0}^{0}}{\frac{\vec{a}}{\Xi}}$ & $\begin{array}{l}\stackrel{0}{0} \\
\stackrel{0}{0} \\
\stackrel{0}{0} \\
\underline{0}\end{array}$ & 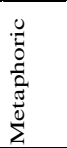 & $\stackrel{\widetilde{J}}{0}$ \\
\hline Attitude & 1.00 & & & & & & & & & & & & & & & & & & & & & & & \\
\hline Visual & 0.24 & 1.00 & & & & & & & & & & & & & & & & & & & & & & \\
\hline Auditory & -0.04 & -0.15 & 1.00 & & & & & & & & & & & & & & & & & & & & & \\
\hline Tactile - kinesthet & 0.20 & 0.32 & 0.44 & 1.00 & & & & & & & & & & & & & & & & & & & & \\
\hline Extroverted & 0.40 & 0.21 & 0.08 & 0.39 & 1.00 & & & & & & & & & & & & & & & & & & & \\
\hline Introverted & -0.12 & -0.13 & 0.33 & 0.05 & -0.52 & 1.00 & & & & & & & & & & & & & & & & & & \\
\hline Random & 0.36 & 0.14 & 0.30 & 0.45 & 0.43 & -0.13 & 1.00 & & & & & & & & & & & & & & & & & \\
\hline Concrete & 0.03 & 0.06 & 0.43 & 0.23 & -0.13 & 0.37 & 0.22 & 1.00 & & & & & & & & & & & & & & & & \\
\hline Closure & 0.11 & 0.36 & -0.09 & -0.01 & 0.24 & -0.15 & 0.51 & 0.29 & 1.00 & & & & & & & & & & & & & & & \\
\hline open & 0.12 & 0.03 & 0.33 & 0.34 & 0.11 & 0.12 & -0.01 & 0.11 & -0.29 & 1.00 & & & & & & & & & & & & & & \\
\hline Global & 0.11 & 0.11 & 0.27 & 0.21 & -0.09 & 0.10 & 0.21 & 0.41 & 0.00 & 0.25 & 1.00 & & & & & & & & & & & & & \\
\hline Particular & 0.13 & 0.22 & 0.17 & 0.55 & 0.30 & -0.06 & 0.37 & 0.39 & 0.21 & 0.02 & -0.01 & 1.00 & & & & & & & & & & & & \\
\hline Sythesizing & 0.01 & -0.02 & 0.26 & 0.21 & 0.26 & -0.22 & 0.36 & 0.23 & 0.45 & 0.19 & 0.18 & -0.01 & 1.00 & & & & & & & & & & & \\
\hline Analytical & -0.15 & -0.23 & 0.26 & 0.22 & -0.01 & 0.41 & 0.09 & 0.40 & 0.08 & -0.06 & -0.04 & 0.31 & 0.03 & 1.00 & & & & & & & & & & \\
\hline Sharpener & -0.07 & -0.07 & -0.04 & -0.16 & 0.16 & -0.11 & 0.43 & 0.03 & 0.66 & -0.26 & -0.01 & -0.02 & 0.60 & 0.15 & 1.00 & & & & & & & & & \\
\hline Leveler & 0.08 & 0.35 & 0.08 & 0.28 & 0.18 & -0.05 & -0.09 & 0.31 & 0.18 & 0.29 & 0.43 & 0.02 & 0.18 & 0.04 & -0.17 & 1.00 & & & & & & & & \\
\hline Deductive & 0.12 & -0.04 & -0.05 & -0.05 & 0.15 & -0.10 & 0.12 & -0.09 & 0.27 & -0.10 & 0.16 & 0.08 & 0.37 & -0.16 & 0.47 & -0.04 & 1.00 & & & & & & & \\
\hline Inductive & 0.54 & 0.12 & 0.27 & 0.05 & 0.15 & 0.32 & 0.14 & 0.22 & 0.10 & 0.13 & 0.31 & -0.11 & 0.02 & 0.05 & -0.10 & 0.24 & 0.21 & 1.00 & & & & & & \\
\hline Field-independent & 0.08 & 0.02 & 0.33 & 0.11 & 0.17 & 0.06 & 0.50 & 0.33 & 0.43 & 0.28 & 0.21 & 0.04 & 0.75 & 0.12 & 0.51 & 0.05 & 0.26 & 0.29 & 1.00 & & & & & \\
\hline Dependent & 0.31 & 0.54 & 0.17 & 0.40 & 0.09 & 0.03 & 0.00 & 0.15 & -0.07 & 0.28 & 0.31 & 0.19 & -0.05 & -0.13 & -0.30 & 0.42 & 0.08 & 0.24 & 0.00 & 1.00 & & & & \\
\hline Impulsive & 0.16 & 0.03 & 0.32 & 0.46 & 0.65 & -0.30 & 0.48 & 0.02 & 0.19 & 0.11 & -0.05 & 0.33 & 0.57 & 0.21 & 0.34 & 0.00 & 0.19 & -0.12 & 0.43 & 0.06 & 1.00 & & & \\
\hline Reflective & 0.06 & 0.23 & 0.14 & 0.02 & -0.15 & 0.38 & 0.09 & 0.50 & 0.26 & 0.16 & 0.40 & 0.00 & 0.04 & 0.43 & 0.04 & 0.44 & -0.25 & 0.40 & 0.32 & 0.29 & -0.13 & 1.00 & & \\
\hline Metaphoric & 0.05 & -0.19 & 0.32 & 0.24 & 0.16 & 0.17 & 0.02 & 0.27 & -0.22 & 0.31 & 0.28 & 0.15 & 0.06 & 0.43 & -0.32 & 0.24 & -0.11 & 0.36 & 0.24 & 0.15 & 0.17 & 0.38 & 1.00 & \\
\hline Literal & 0.33 & 0.26 & -0.11 & 0.09 & 0.21 & -0.17 & 0.15 & -0.10 & 0.30 & -0.18 & -0.13 & 0.15 & 0.07 & -0.14 & 0.31 & 0.06 & 0.27 & -0.10 & -0.10 & 0.03 & 0.09 & -0.28 & -0.61 & 1.00 \\
\hline
\end{tabular}


Table 2

Pearson's Correlation Coefficient between learning styles and attitudes toward computers in general

\begin{tabular}{|c|c|c|c|c|c|c|c|c|c|c|c|c|c|c|c|c|c|c|c|c|c|c|c|c|c|c|}
\hline & 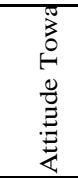 & 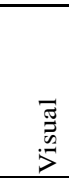 & 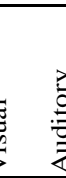 & . & 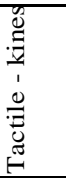 & 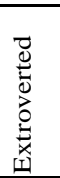 & $\begin{array}{l}\vec{D} \\
\stackrel{0}{0} \\
0 \\
0 \\
\Xi \\
\Xi\end{array}$ & 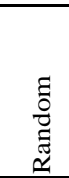 & $\begin{array}{l}\frac{0}{0} \\
0 \\
0 \\
0\end{array}$ & $\begin{array}{ll}0 \\
0 \\
0 \\
0 \\
0 \\
0 \\
0 \\
0 \\
0\end{array}$ & שֶ & 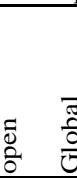 & 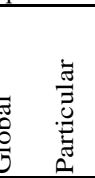 & 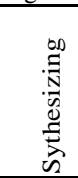 & 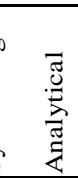 & 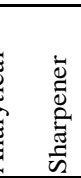 & 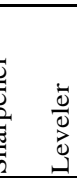 & 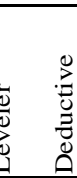 & & 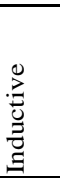 & 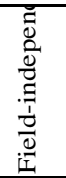 & $\begin{array}{l}\overrightarrow{0} \\
\overline{0} \\
\overline{0} \\
\overline{0} \\
0\end{array}$ & 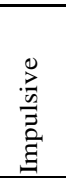 & 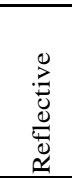 & $\begin{array}{l}\frac{0}{0} \\
\frac{0}{2} \\
\frac{\pi}{2} \\
\sum^{0}\end{array}$ & 苞 \\
\hline Attitude Toward & 1.0 & & & & & & & & & & & & & & & & & & & & & & & & & \\
\hline Visual & -0.16 & $\begin{array}{ll}6 & 1.0\end{array}$ & 00 & & & & & & & & & & & & & & & & & & & & & & & \\
\hline Auditory & -0.08 & $8-0.1$ & 151. & 1.00 & & & & & & & & & & & & & & & & & & & & & & \\
\hline Tactile - kinesthe & e -0.1 & $\begin{array}{lll}1 & 0.32\end{array}$ & 320. & $0.44 \quad 1$ & 1.00 & & & & & & & & & & & & & & & & & & & & & \\
\hline Extroverted & 0.15 & $\begin{array}{ll}5 & 0.2\end{array}$ & 210. & $0.08 \quad 0$ & 0.39 & 1.00 & & & & & & & & & & & & & & & & & & & & \\
\hline Introverted & -0.18 & $8-0.1$ & 130. & 0.330 & 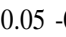 & -0.52 & 1.00 & & & & & & & & & & & & & & & & & & & \\
\hline Random & 0.3( & $\begin{array}{lll}0 & 0.1\end{array}$ & 140. & 0.300 & 0.45 & 0.43 & -0.13 & 31.00 & & & & & & & & & & & & & & & & & & \\
\hline Concrete & 0.08 & & 060. & $0.43 \quad 0$ & $0.23-(-x-2)$ & -0.13 & 0.37 & $\begin{array}{ll}7 & 0.22 \\
-1\end{array}$ & $22 \quad 1.0$ & 00 & & & & & & & & & & & & & & & & \\
\hline Closure & $0.0 \mathrm{c}$ & & $36-0$. & $0.09-0$ & 0.01 & 0.24 & -0.15 & $5 \quad 0.51$ & $51 \quad 0.2$ & 291.0 & .00 & & & & & & & & & & & & & & & \\
\hline open & 0.18 & $\begin{array}{ll}8 & 0.0\end{array}$ & 030. & 0.330 & 0.34 & 0.11 & 0.12 & $2-0.01$ & 010.1 & $11-0.2$ & .291. & 1.00 & & & & & & & & & & & & & & \\
\hline Global & $-0.02-2$ & 20.1 & 110. & $0.27 \quad 0$ & 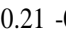 & -0.09 & 0.10 & $\begin{array}{ll}0 & 0.21\end{array}$ & 210.4 & $\begin{array}{ll}41 & 0.0\end{array}$ & .000. & .251 .0 & .00 & & & & & & & & & & & & & \\
\hline Particular & -0.1 & & 220. & 0.170 & 0.55 & 0.30 & -0.06 & $\begin{array}{ll}6 & 0.37\end{array}$ & $37 \quad 0.3$ & $\begin{array}{ll}39 & 0.2\end{array}$ & .210. & $.02-0$. & $.01 \quad 1.00$ & & & & & & & & & & & & & \\
\hline Sythesizing & 0.13 & $3-0.02$ & 020. & 0.260 & 0.21 & 0.26 & -0.22 & 20.36 & $\begin{array}{ll}36 & 0.2\end{array}$ & 230.4 & 450. & .190 .1 & $18-0.01$ & 11.00 & 00 & & & & & & & & & & & \\
\hline Analytical & -0.12 & $2-0.2$ & 230. & 0.260 & $0.22-(-1-x-2)$ & -0.01 & 0.41 & 10.09 & 990.4 & $\begin{array}{ll}40 & 0.0\end{array}$ & . $08-0$. & $.06-0.6$ & $.04 \quad 0.31$ & $\begin{array}{ll}31 & 0.03\end{array}$ & $03 \quad 1.00$ & 00 & & & & & & & & & & \\
\hline Sharpener & -0.0 & $5-0.0$ & $07-0$. & $0.04-0$ & 0.16 & 0.16 & -0.11 & 10.43 & $43 \quad 0.0$ & $03 \quad 0.6$ & $66-0$. & $.26-0$. & $.01-0.02$ & 220.60 & 600.15 & 151.00 & 00 & & & & & & & & & \\
\hline Leveler & 0.02 & 20.3 & 350. & $0.08 \quad 0$ & 0.28 & 0.18 & -0.05 & $5-0.09$ & 990.3 & $\begin{array}{ll}31 & 0.1\end{array}$ & 180. & .290 .4 & $43 \quad 0.02$ & 20.18 & $18 \quad 0.04$ & $04-0.17$ & $17 \quad 1.0$ & .00 & & & & & & & & \\
\hline Deductive & -0.1 & $1-0.0$ & $04-0$. & $0.05-0$ & 0.05 & 0.15 & -0.10 & 00.12 & $12-0.0$ & $\begin{array}{ll}09 & 0.2\end{array}$ & $27-0$. & .100 .1 & 160.08 & $\begin{array}{ll}88 & 0.37\end{array}$ & $37-0.16$ & 160.47 & $47-0.0$ & $.04 \quad 1.0$ & & & & & & & & \\
\hline Inductive & 0.3 & $\begin{array}{ll}3 & 0.12\end{array}$ & 120. & $0.27 \quad 0$ & 0.05 & 0.15 & 0.32 & 20.14 & $14 \quad 0.2$ & 220.1 & 100. & .130 .3 & $.31-0.11$ & 110.02 & $02 \quad 0.05$ & $05-0.10$ & $10 \quad 0.2$ & $24 \quad 0.2$ & 211 & 1.00 & & & & & & \\
\hline Field-independer & r. $\quad 0.19$ & & 020. & 0.330 & 0.11 & 0.17 & 0.06 & 60.50 & $\begin{array}{ll}50 & 0.3\end{array}$ & $\begin{array}{ll}33 & 0.4\end{array}$ & .430. & $\begin{array}{ll}28 & 0.2\end{array}$ & $21 \quad 0.04$ & $4 \quad 0.75$ & $\begin{array}{ll}75 & 0.12\end{array}$ & 120.5 & $\begin{array}{ll}51 & 0.0\end{array}$ & $\begin{array}{ll}05 & 0.2\end{array}$ & .260 & 0.29 & 1.00 & & & & & \\
\hline Dependent & 0.0 & $\begin{array}{ll}0 & 0.5 \\
\end{array}$ & 540. & $0.17 \quad 0$ & 0.40 & 0.09 & 0.03 & $\begin{array}{ll}3 & 0.00 \\
-\end{array}$ & 00.1 & $15-0.0$ & $.07 \quad 0.2$ & .280 .3 & $\begin{array}{ll}.31 & 0.19\end{array}$ & $19-0.05$ & $05-0.13$ & $13-0.30$ & $30 \quad 0.4$ & $42 \quad 0.0$ & .080 & 0.24 & & 1.00 & & & & \\
\hline Impulsive & 0.02 & 20.0 & 030. & 0.320 & 0.46 & 0.65 & -0.30 & $\begin{array}{ll}0 & 0.48\end{array}$ & $\begin{array}{ll}48 & 0.02\end{array}$ & $\begin{array}{ll}02 & 0.1\end{array}$ & 190. & $.11-0$. & $\begin{array}{ll}.05 & 0.33\end{array}$ & $\begin{array}{ll}33 & 0.57\end{array}$ & $\begin{array}{ll}57 & 0.21\end{array}$ & $21 \quad 0.3$ & $\begin{array}{ll}34 & 0.0\end{array}$ & $\begin{array}{ll}00 & 0.1\end{array}$ & $19-0$ & 0.12 & & 0.06 & 1.00 & & & \\
\hline Reflective & 0.1( & $\begin{array}{ll}0 & 0.2\end{array}$ & 230. & 0.140 & $0.02-(-1)-x$ & -0.15 & 0.38 & 80.09 & 990.5 & $\begin{array}{ll}50 & 0.2\end{array}$ & .260. & .160 .4 & $\begin{array}{ll}.40 & 0.00\end{array}$ & 00.04 & 040.43 & $43 \quad 0.02$ & $04 \quad 0.4$ & $44-0.2$ & .250 & 0.40 & & 0.29 & -0.13 & 1.00 & & \\
\hline Metaphoric & 0.0 & $5-0.19$ & 190. & 0.320 & 0.24 & 0.16 & 0.17 & $7 \quad 0.02$ & $2 \quad 0.2$ & $27-0.2$ & .220. & .310 .2 & .280 .15 & 150.06 & $\begin{array}{ll}06 & 0.43\end{array}$ & $43-0.32$ & $\begin{array}{ll}32 & 0.2\end{array}$ & $24-0.1$ & 110 & 0.36 & & 0.15 & 0.17 & 0.38 & $\begin{array}{ll}8 & 1.00\end{array}$ & \\
\hline Literal & 0.0 & & $26-0$. & 0.110 & 0.09 & 0.21 & -0.17 & $\begin{array}{ll}7 & 0.15 \\
\end{array}$ & $15-0.1$ & $\begin{array}{ll}10 \quad 0.3 \\
\end{array}$ & $30-0$. & $.18-0.1$ & $\begin{array}{ll}13 & 0.15 \\
\end{array}$ & 150.07 & $07-0.14$ & $\begin{array}{ll}14 & 0.3 \\
\end{array}$ & $\begin{array}{ll}31 & 0.0 \\
\end{array}$ & $06 \quad 0.2$ & $.27-0$ & 0.10 & -0.10 & 0.03 & 0.09 & -0.28 & & 611.00 \\
\hline \multicolumn{27}{|c|}{ 1. } \\
\hline & 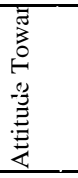 & 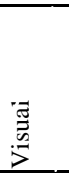 & $\begin{array}{l}\frac{8}{3} \\
\frac{3}{3} \\
\end{array}$ & 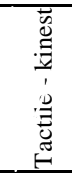 & 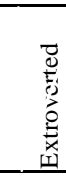 & & 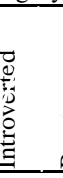 & 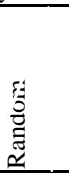 & 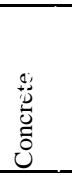 & 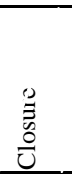 & $\begin{array}{l}\text { एँ } \\
\text { ठे }\end{array}$ & 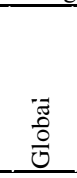 & 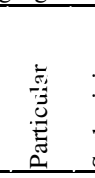 & 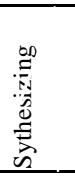 & 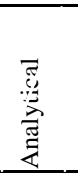 & 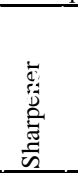 & مَّ & 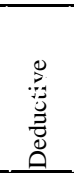 & 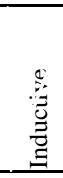 & 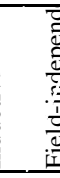 & 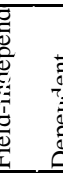 & 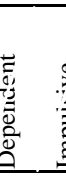 & 品 & 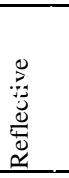 & 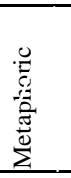 & 苞 \\
\hline Attitude Towa & 1.00 & & & & & & & & & & & & & & & & & & & & & & & & & \\
\hline Visual & 0.08 & 1.00 & & & & & & & & & & & & & & & & & & & & & & & & \\
\hline Auditory & $0.01-($ & -0.15 & 1.00 & & & & & & & & & & & & & & & & & & & & & & & \\
\hline Tactile - kines 1 & 0.12 & 0.32 & 0.44 & $\begin{array}{ll}4 & 1.00\end{array}$ & & & & & & & & & & & & & & & & & & & & & & \\
\hline Extroverted & 0.18 & 0.21 & 0.08 & $\begin{array}{ll}8 & 0.39\end{array}$ & $\begin{array}{ll}9 & 1.0\end{array}$ & & & & & & & & & & & & & & & & & & & & & \\
\hline Introverted & $0.19-($ & -0.13 & 0.33 & $\begin{array}{ll}3 & 0.05\end{array}$ & $5-0.5$ & & 1.00 & & & & & & & & & & & & & & & & & & & \\
\hline Random & 0.26 & 0.14 & 0.30 & $\begin{array}{ll}0 & 0.45\end{array}$ & 150.4 & $43-0$. & .131 & 1.00 & & & & & & & & & & & & & & & & & & \\
\hline Concrete & 0.28 & 0.06 & 0.43 & $\begin{array}{ll}3 & 0.23\end{array}$ & $23-0.1$ & 130. & .370 & 0.22 & 1.00 & & & & & & & & & & & & & & & & & \\
\hline Closure & 0.30 & $0.36-$ & -0.09 & $9-0.01$ & $\begin{array}{ll}1 & 0.2\end{array}$ & $24-0$. & .150 & 0.51 & 0.29 & 1.00 & & & & & & & & & & & & & & & & \\
\hline open & 0.09 & 0.03 & 0.33 & $\begin{array}{ll}3 & 0.34\end{array}$ & $\begin{array}{ll}4 & 0.1\end{array}$ & 110. & $.12-0$ & 0.01 & $0.11-$ & -0.29 & 1.00 & & & & & & & & & & & & & & & \\
\hline Global & -0.03 & 0.11 & 0.27 & $\begin{array}{ll}7 & 0.21\end{array}$ & $21-0.0$ & 090. & .100 & 0.21 & 0.41 & 0.00 & 0.25 & 51.00 & & & & & & & & & & & & & & \\
\hline Particular & 0.10 & 0.22 & 0.17 & $\begin{array}{ll}7 & 0.55\end{array}$ & $\begin{array}{ll}5 & 0.3\end{array}$ & $30-0$. & .060 & 0.37 & 0.39 & 0.21 & 0.02 & $2-0.01$ & 1.00 & & & & & & & & & & & & & \\
\hline Syth & $0.05-($ & -0.02 & 0.26 & 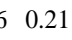 & 210.2 & $26-0$. & .220 & 0.36 & 0.23 & 0.45 & 0.19 & 0.18 & $\begin{array}{ll}-0.01 \quad 1 & 1\end{array}$ & 1.00 & & & & & & & & & & & & \\
\hline Analytical & $0.24-($ & -0.23 & 0.26 & 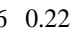 & $22-0.0$ & 010. & 0.410 & 0.09 & 0.40 & $0.08-$ & -0.06 & $5-0.04$ & +0.310 & 0.03 & 1.00 & & & & & & & & & & & \\
\hline Sharpener & $-0.01-($ & $-0.07-$ & -0.04 & $4-0.16$ & $\begin{array}{ll}6 & 0.1\end{array}$ & $16-0$. & .110 & 0.43 & 0.03 & $0.66-$ & -0.26 & $5-0.01$ & -0.02 & 0.60 & 0.15 & 1.00 & & & & & & & & & & \\
\hline Leveler & 0.21 & 0.35 & 0.08 & 80.28 & $\begin{array}{ll}28 & 0.1\end{array}$ & $18-0$. & $.05-0$ & 0.09 & 0.31 & 0.18 & 0.29 & 0.43 & 30.020 & 0.18 & $0.04-$ & -0.17 & 1.00 & & & & & & & & & \\
\hline Deductive & $-0.23-($ & $-0.04-$ & -0.05 & $5-0.05$ & $\begin{array}{ll}5 & 0.1\end{array}$ & $15-0$. & .100 & $0.12-($ & -0.09 & $0.27-$ & -0.10 & 0.16 & $5 \quad 0.08 \quad 0$ & $0.37-$ & -0.16 & 0.47 & -0.04 & 1.00 & & & & & & & & \\
\hline Inductive & 0.43 & 0.12 & 0.27 & $\begin{array}{ll}7 & 0.05\end{array}$ & $\begin{array}{ll}5 & 0.1\end{array}$ & 150. & .320 & 0.14 & 0.22 & 0.10 & 0.13 & 0.31 & -0.110 & 0.02 & $0.05-$ & -0.10 & 0.24 & 0.21 & 1.00 & 00 & & & & & & \\
\hline Field-indepenc & 0.28 & 0.02 & 0.33 & 30.11 & $\begin{array}{ll}1 & 0.1\end{array}$ & 170. & .060 & 0.50 & 0.33 & 0.43 & 0.28 & 0.21 & 0.040 & 0.75 & 0.12 & 0.51 & 0.05 & 0.26 & $\begin{array}{ll}5 & 0.29\end{array}$ & 291. & .00 & & & & & \\
\hline lent & -0.06 & 0.54 & 0.17 & $\begin{array}{ll}7 & 0.40\end{array}$ & $10 \quad 0.0$ & 090. & .030 & 0.00 & $0.15-$ & -0.07 & 0.28 & 0.31 & $0.19-0$ & $-0.05-($ & $-0.13-$ & -0.30 & 0.42 & 0.08 & 0.24 & 240. & .001. & .00 & & & & \\
\hline In & 0.13 & 0.03 & 0.32 & 20.46 & $16 \quad 0.6$ & $65-0$. & .300 & 0.48 & 0.02 & 0.19 & 0.11 & -0.05 & 50.330 & 0.57 & 0.21 & 0.34 & 0.00 & 0.19 & -0.12 & 120. & 430. & $.06 \quad 1$ & 1.00 & & & \\
\hline & 0.47 & 0.23 & 0.14 & $\begin{array}{l}4 \quad 0.02 \\
4\end{array}$ & $2-0.1$ & 150. & .380 & 0.09 & 0.50 & 0.26 & 0.16 & 50.40 & 0.000 & 0.04 & 0.43 & 0.04 & 0.44 & -0.25 & 50.40 & 400. & 320. & $29-0$ & 0.13 & 1.00 & & \\
\hline & $0.19-$ & -0.19 & 0.32 & 20.24 & 240.1 & 160. & .170 & 0.02 & $0.27-$ & -0.22 & 0.31 & 0.28 & 30.150 & 0.06 & $0.43-$ & -0.32 & 0.24 & -0.11 & 0.36 & $\begin{array}{ll}36 & 0 .\end{array}$ & .240 . & 150 & 0.17 & 0.38 & 1.00 & \\
\hline Literal & -0.11 & $0.26-$ & -0.11 & $\begin{array}{l}1 \quad 0.09 \\
\end{array}$ & $\begin{array}{ll}9 & 0.2 \\
\end{array}$ & $21-0$. & 0.170 & (- & -0.10 & $0.30-$ & -0.18 & -0.13 & 0.150 & $0.07-$ & -0.14 & 0.31 & 0.06 & 0.27 & -0.10 & $10-0$. & 100. & $\begin{array}{ll}03 & 0\end{array}$ & (- 0.09 & $-0.28-$ & -0.61 & 1.00 \\
\hline
\end{tabular}

+0.40 for extroverted, and +0.54 for inductive learning styles. As a result of the analysis, a positive scale, moderately significant relationship was found between extroverted and inductive learning styles of students, and their attitudes toward second language learning (Table 1). The same correlation was conducted with the second part results of Min's Questionnaire to find out the correlation between learning styles and attitudes 
toward computers in general. As shown in Table 2, any significant correlation was not found between the variables $(r<0.4)$. When the data conducted again for attitudes toward CALL (Table 3$)$, a positive moderate scale correlation was found between inductive and reflective learning styles, and attitudes toward CALL. The value of $r$ for inductive is +0.43 and for reflective $+0.47(r>0.40)$.

\subsection{Research Question 2}

The answers for Min's (1998) survey were calculated with regard to the second research question: whether there is a difference between ESL and EFL learners' attitude toward second language learning and computer-assisted language learning, Because of that, all the nominal data in this 5-point Likert scale turned into numerical values, with 1- Strongly Disagree, 2- Disagree, 3-Uncertain, 4-Agree, 5-Strongly Agree. Then, the data gathered from the subjects' answers were averaged to get the mean scores for each item. The standard deviation of all items was calculated in order to understand their proximity to the mean. The participant sample was separated into two groups: ESL and EFL learners. Table 2 shows descriptive data for ESL and EFL learners. In the sample, there were 19 ESL learners and 11 EFL learners. ESL learners spent time studying English as a second language for 15.8 years on average, while EFL learners studied one of the languages among French, Turkish, Russian, Polish, ASL and Spanish as a foreign language for 18.5 years. T-tests were conducted to learn of any correlation between time spent studying a language, and their attitude toward language learning between the two samples. Also, the same correlation between time spent studying a language with computers was calculated. No statistically significant result was found. However, Table 4 showed the results of t-test, and found that there was a significant difference between ESL and EFL learners' attitudes toward second language learning $[t(18)=2.11, p<.05]$ and computer assisted language learning $[t(28)=2.09, p<.05]$.

Table 4. T-test results of the learning style preferences of students and their attitude levels

\begin{tabular}{|l|l|l|l|l|l|l|}
\hline Attitude & Learners & \multicolumn{1}{|c|}{$\boldsymbol{N}$} & \multicolumn{1}{|c|}{$\overline{\boldsymbol{x}}$} & \multicolumn{1}{|c|}{$\boldsymbol{d f}$} & \multicolumn{1}{|c|}{$\boldsymbol{T}$} \\
\hline Attitudes Toward Second Language Learning & ESL & 19 & 4.22 & 18 & 2.11 & 0.00 \\
\hline & EFL & 11 & 3.65 & & & \\
\hline Attitudes Toward Computers in General & ESL & 19 & 3.85 & 23 & 2.07 & 0.00 \\
\hline & EFL & 11 & 2.42 & & & \\
\hline Attitudes Toward CALL & ESL & 19 & 3.44 & 28 & 2.09 & 0.00 \\
\hline & EFL & 11 & 3.00 & & & \\
\hline
\end{tabular}

Table 5. ESL -EFL Learners Attitude Toward Second Language Learning

\begin{tabular}{|l|l|l|}
\hline Attitudes Towards Language Learning with Computers & ESL & EFL \\
\hline Items & Mean & Mean \\
\hline 1. Learning L2 will be helpful for me in obtaining a job and earning a living.. & 4.8 & 3.5 \\
\hline 2. Conversing with an L2 instructor is a good method of studying L2. & 4.4 & 4.1 \\
\hline 3. Speaking with native speakers of L2 is a shortcut to improve my speaking skills. & 4.6 & 4.0 \\
\hline 4. Repetition drills are useful in learning conversational L2. & 3.9 & 3.1 \\
\hline 5. To master L2, you ought to think in L2.. & 4.4 & 3.4 \\
\hline 6. When learning to speak L2, grammar should not be emphasized. & 3.1 & 2.2 \\
\hline 7. Learning about the culture of language is an important step in L2. & 4.0 & 4.2 \\
\hline 8. In learning to speak L2, you must not be afraid to make mistake. & 4.5 \\
\hline 9. Keeping an L2 diary is a good way to improve my writing ability. & 4.6 \\
\hline 10. Correct pronunciation is important in learning L2. & 3.6 & 3.5 \\
\hline 11. To speak L2 fluently, self-confidence is important. & 4.3 & 3.8 \\
\hline 12. You should memorize a lot of words to improve your conversational skills. & 4.6 & 4.3 \\
\hline 13. The most important thing in learning L2 is conversational skills. & 4.0 & 2.9 \\
\hline 14. The best time to learn language as a foreign or second language is as a small child. & 4.2 & 3.6 \\
\hline 15. L2 speaking ability is essential in international communication. & 4.2 & 3.9 \\
\hline
\end{tabular}


It can be concluded from Table 5 that the mean scores of items 1, 5, 6, 12 and 15 in Min's questionnaire were considerably different when ESL and EFL learners were compared. ESL learners agreed strongly to the statements of these items while EFL learners were uncertain or disagreed with these items (1-Strongly Disagree, 2- Disagree, 3-Uncertain, 4-Agree, 5-Strongly Agree). Item 1, 'Learning L2 will be helpful for me in obtaining a job and earning a living,' is the most agreed one among all fifteen items by ESL learners. As for EFL learners, item 7 and 8 were two items on which they agreed more than ESL learners. On the other hand, for all the learners, item 8 ('In learning to speak L2, you must not be afraid to make mistakes') was the one they agreed upon (ESL - 4.5 and EFL - 4.6). In addition, item 6 'When learning to speak L2, grammar should not be emphasized' shows how they differ about grammar instruction. ESL learners agree with this statement (3.1), while EFL learners disagree (2.2). Overall, it was concluded from this table that ESL and EFL learners' attitudes varied regarding the items in the questionnaire.

Table 6. ESL -EFL Learners Attitude Toward Language Learning with Computers

\begin{tabular}{|l|l|l|}
\hline Attitudes Towards Language Learning with Computers & ESL & EFL \\
\hline Items & Mean & Mean \\
\hline 1. Using CD-ROM programs is an effective way to learn how to speak L2. & 3.6 & 3.1 \\
\hline 2. Computers are not helpful for learning L2 conversation. & 2.5 & 2.6 \\
\hline 3. Chatting with native speakers on the Internet is helpful for learning L2. & 4.4 & 3.7 \\
\hline $\begin{array}{l}\text { 4. The reason why I don't study L2 with computer is that there is no good computer software for } \\
\text { learning L2. }\end{array}$ & 2.5 & 2.6 \\
\hline 5. Studying L2 with computers is boring. & 2.4 & 2.8 \\
\hline 6. Studying L2 with a computer will enhance my speaking ability. & 3.3 & 3.2 \\
\hline 7. Using a computer to study L2 improves speaking proficiency. & 3.6 & 3.2 \\
\hline 8. Learning L2 by computers is impossible without technical computer knowledge. & 2.8 & 2.5 \\
\hline 9. Computers can assist in learning L2 faster. & 4.0 & 3.4 \\
\hline $\begin{array}{l}\text { 10. Interactive role-playing with the computer makes me less nervous than talking with foreigners } \\
\text { directly. }\end{array}$ & 3.1 & 2.8 \\
\hline $\begin{array}{l}\text { 11. Worldwide travel through the Internet helps me to understand the culture of L2-speaking } \\
\text { countries. }\end{array}$ & 3.8 & 3.5 \\
\hline $\begin{array}{l}\text { 12. My incorrect pronunciation can be corrected through computer graphics which show how } \\
\text { native speakers pronounce L2 sounds. }\end{array}$ & 4.2 & 2.7 \\
\hline 13. Taking writing courses through the Internet can improve written Competence in L2. & 3.8 & 3.3 \\
\hline 14. I am eager to study L2 by computer. & 3.8 & 2.8 \\
\hline 15. I can cover more material on my own when I study L2 with computers. & 3.7 & 2.7 \\
\hline
\end{tabular}

As a last, it can be concluded from Table 6 that the biggest difference between ESL and EFL learners is determined with the item 12 (ESL- 4.2, EFL-2.7) and 15 (ESL- 3.7, EFL-2.7). ESL learners agreed with these items more than EFL learners. Item 5, 'Studying L2 with computers is boring.' is the item which EFL learners agreed more than ESL learners. As for item 14 which is 'I am eager to study L2 with computers, ESL learners are positive (3.8) while EFL learners are more negative (2.8). Overall, it was concluded from this table that ESL learners more positive compared to EFL learners in terms of language learning with computers.

\section{DISCUSSION}

One of the main findings of this research was that a positive scale moderately significant relationship exists between extroverted and inductive learning styles of students, and their attitudes toward second language learning. It is also concluded that inductive and reflective learning styles were moderately correlated with their attitudes toward second language learning with computers. Considering two results, inductive learning style is related both with attitudes toward language learning and attitudes towards language learning with computers. As for inductive learning style, inductive learners prefer to go from general to specific and to begin with examples rather than rules or theories, according to the explanation in Cohen, Rebecca and Chi's (2002) Learning Style Survey. Prince (2006) explained that inductive instruction presents new information in the context of situations, issues, and problems to which students can relate, so there is a much greater chance that the information can be linked to their existing cognitive structures. Prince (2006) suggested that inductive teaching was related to the contextualization of the issues the students learn. Furthermore, Loewen et al. (2009) reported that learners preferred grammar instruction that involved contextualized examples and explanations, as well as activities that required interaction. In their study, many learners stated that they did not like memorization and to be given a list of grammar rules (Loewen et al, 2009, p. 101). One of the 
conclusions of their study is that students prefer inductive teaching instead of deductive instruction. In this sense, another further question arises, whether this kind of learner's style preference for learning a language may result in changes for a language teaching method, from deductive to inductive language instruction. Also, in this sense, Prince (2006) added in their study that simply telling students that they would need certain knowledge and skills someday was not a particularly effective motivator, and a preferable alternative was inductive teaching and learning. Therefore, this current study supported these explanations that inductive learners more positive toward language learning, even for online courses.

The second finding of the study was that there was a significant difference between ESL and EFL learners' attitudes toward language learning. The reason may be that ESL learners are more motivated to get a job or earn a living, contrary to EFL learners. As Loewen et al. (2009) concluded in their study, there were varied beliefs about grammar instruction and error correction between ESL and EFL learners. The current study supports the conclusions of Loewen et al. (2009) because it is found that EFL learners are more positive to learn language by giving importance to grammar. There was also an important difference between the two groups about language learning with computers. ESL learners are more positive to learn with computers. The reason for this may be that there are more language learning software programs or online classes for English as an international language than the other languages. Therefore, foreign language learners may not take advantage of using computers as much as ESL learners.

\section{CONCLUSION AND IMPLICATIONS}

This study aimed to investigate if there was a correlation between learning styles and the attitudes of students toward computer-assisted language learning. The other goal of this study was to find out if there were differences between ESL-EFL language learners. The results of the study support that extroverted and inductive language learning styles moderately correlated with language learning as a result of statistical analysis. Also, inductive and reflective learning style was moderately correlated with their attitude toward language learning with computers.

In addition, it was found that ESL learners were more positive toward computer-assisted language learning. Further findings suggest that inductive language teaching method can be applied to the language learning software programs as well as to the online classrooms. Because inductive learning is supported with contextualized learning, teachers can prepare their materials according to the context they choose as a topic. In line with that, software designers can organize their software programs according to the needs of the students in terms of inductive learning. They can create a program which gives examples before the rules. Also, the manner in which ESL and EFL learners are taught should be different. ESL teachers may organize their classes' activities based more on job admissions or earning a living, because as the study concluded, two groups' attitudes toward language learning are different.

As for the limitation of the study, there was a small sample size with twenty-six variables considered. More accurate results can be found when researchers increase the sample size for future research. In addition, the sample size was chosen via the snowball sampling method and all the people are from the same environment and background. Therefore, the sample size may not reflect the real population because the people from different background such as engineering, nursing, business may be more positive towards computer-assisted language learning as EFL learners. Therefore, the gap between the two groups may not be significant as the results show in this current study. In spite of these limitations, this pilot research will be a good guideline for further research on learning styles and attitudes toward computer-assisted language learning, as little research has been done on this correlation. In line with this study's findings, further study may be done especially on deductive and inductive learning styles in order to understand how they affect language learning. Other further research focus may be on the differences between ESL and EFL learners so as to find out their motivation to learn a language with computers.

\section{NOTES}

1- Throughout the research, computer-assisted language learning is considered not only learning a language with computers as a learning tool with its software programs but also learning a language in online classes via computers. Therefore, some suggestions were given to language teachers as well.

2- For the purposes of this study, the second language referred only to learners of English, whereas foreign language referred to learners of any other language.

3- Learning styles questionnaires are generally considered separately either ability based or personality based. In this study, the questionnaire that was used for this study included all the preferences of learning styles as a whole. 


\section{REFERENCE LIST}

Boneva, D. \& Mihavo, E. (2012). Dyslang Module 8 - Learning Styles and Learning Preferences. The Dyslexia Association, 1-32. Retrieved from http://dyscovery.research.southwales.ac.uk/media/files/documents/2014-01-16/Module_8.pdf

Brudenell, I., Carpenter, C. (1990). Adult Learning Styles and Attitudes Toward Computer Assisted Instruction. Journal of Nursing Education, 29 (2), 79-83. Retrieved from https://www.researchgate.net/publication/21000622_Adult_learning_styles_and_attitudes_toward_com puter_assisted_instruction

Caliskan, H., Kilinc, G. (2012). The Relationship Between the Learning Styles of Students and Their Attitudes Towards Social Studies Course. Procedia - Social and Behavioral Sciences, 55, 47-56. Retrieved from at www.sciencedirect.com

Cesur, M. O., Fer, S. ( 2009). What is validity and reliability study of learning style survey. Journal of Theory and Practice in Education, 5(2), 289-314.

Cohen, A. D., Oxford, R. L., \& Chi, J. C. (2002). Learning Style Survey: Assessing Your Own Learning Styles. Minneapolis, MN: Center for Advanced Research on Language Acquisition.

Cohen, A. D. \& Weaver, S. J. (2006). Styles and strategies-based instruction: A teachers' guide. Minneapolis, MN: Center for Advanced Research on Language Acquisition, University of Minnesota.

Gomleksiz, M. (2010). An evaluation of students' attitudes toward English language learning in Terms of several variables. Procedia - Social and Behavioral Sciences, 9, 913-918. https://doi.org/10.1016/j.sbspro.2010.12.258

Husseina, G., Ddemirok, M. and Uzunboylu, H. (2009). Undergraduate student's attitudes towards English language. Procedia Social and Behavioral Sciences, 1, 431-433. Retrieved from www.sciencedirect.com

Kara, S. (2009). Learning Styles and Teaching Styles: A Case Study in Foreign Language Classroom. Conference of the International Journal of Arts and Sciences, 1(20), 77 - 82. Retrieved from http://www.openaccesslibrary.org/images/BOS134_Selma_Kara.pdf

Lee, B. and Kim, H. (2014). What Can We Learn from Our Learners' Learning Styles? English Language Teaching, 7 (9), 118- 131. doi:10.5539/elt.v7n9p118

Loewen, S, Li, S., Fei, F., Thompson, A., Nakatsukasa, K., Ahn, S., Chen, X. (2009). Second Language Learners' Beliefs About Grammar Instruction and Error Correction. The Modern Language Journal, 93, 91-104.

Min, Byoung-chul. (1998). A Study of the Attitudes of Korean Adults toward Technology-Assisted Instruction in English-Language Programs. Multimedia-Assisted Language Learning, 1(1), 63-78.

More, J. A. (1987). Native Indian Learning Styles: A review for researchers and Teachers. Journal of American Indian Education, 27 (1), 17-29. Retrieved from http://www.jstor.org/stable/24397988

Mori, Y. (1999) Epistemological Beliefs and Language Learning Beliefs: What Do Language Learners Believe About Their Learning? Language Learning, 49, 377-415. Retrieved from http://onlinelibrary.wiley.com/doi/10.1111/0023-8333.00094/full

Myftiu, J. (2015). Individual Differences Considering Students' Learning Styles. Psychology Department, Mediterranean Journal of Social Sciences, 6(3), 214-219. doi:10.5901/mjss.2015.v6n3s1p214

Oxford, R. L. (1993). Style analysis survey (SAS). Tuscaloosa, AL: University of Albama.

Oxford, R.L., Ehrman, M., Lavine, R.Z., (1991). Style wars: Teacher-student style conflicts in the language classroom. In: Magnan, S.S. (Ed.). Challenges in the 1990s for College Foreign Language Programs. Heinle and Heinle, Boston, MA.

Prince, J. M. (2006). Inductive Teaching and Learning Methods: Definitions, Comparisons, and Research Bases. J. Engr. Education, 95(2), 123-138.

Pritchard, A. (2014). Ways of Learning: Learning Theories and Learning Styles in the Classroom, 3rd Ed. New York: Routledge Taylor \& Francis Group Press.

Reid, J. M. (1987). The learning style preferences of ESL students. TESOL Quarterly, 21(1), 87-111. 
Retrieved from http://www.tesol.org/read-and-publish/journals/tesol-quarterly

Sirmaci, N. (2010). The relationship between the attitudes towards mathematics and learning styles. Procedia Social and Behavioral Sciences, 9, 644-648. Retrieved from www.sciencedirect.com

Stockwell, G. (2014). Exploring theory in computer-assisted language learning. Alternative Pedagogies in the English Language \& Communication Classroom: Selected Papers from the Fourth CELC Symposium for English Language Teachers, 25-30.

Swailes, S. and Senior, B. (1999). The Dimensionality of Honey and Mumford's Learning Styles Questionnaire. International Journal of Selection and Assessment, 7, 1-11. http://doi.org/10.1111/1468-2389.00099 